\title{
MEDIÁCIÓ A KOMMUNIKÁCIÓ PARTICIPÁCIÓRA ALAPOZOTT FELFOGÁSA SZERINT
}

\author{
Né m e th Viktor \\ manfromreno@gmail.com
}

D O I : 10.20520/JEL - K EP.2019.1.17

\begin{abstract}
Absztrakt
A mediáció a kommunikáció egy olyan speciális alkalmazása, amely elősegíti a konfliktusos felek közötti megértést. Ennek az összetett folyamatnak az elméleti alapon történő ismertetése olyan különleges megértési formákat tár fel, amelyek közelebb hoznak nemcsak a mediáció, de a kommunikáció alaposabb konceptualizációjához is. A tanulmány a mediáció egységeit egy egyedülálló kommunikációs elmélet, a Kommunikáció Participációs Elmélete révén taglalja. Ez az elmélet biztosítja azokat a kategóriákat, amelyekkel a fenti konceptualizáció megvalósulhat. A kategóriák, mint a problémamegoldó ágens, az ágensek problémák felismerésére és megoldására való felkészültsége, az intézmény és a kommunikatív színtér mediációs egységekre vonatkoztatása annak érdekében történik, hogy ezek az egységek kommunikációs alapon kerülhessenek keretezésre, és a megértés mediációs folyamatban betöltött szerepét szemléltessék.
\end{abstract}

\section{Kulcsszavak}

mediáció, participációs elmélet, mediátor, ko-mediátor, protokoll

\section{MEDIATION ACCORDING TO THE PARTICIPA - TION THEORY OF COMMUNICATION}

\section{Viktor Ném eth}

\begin{abstract}
Mediation is a specific application of communication, that facilitates understanding between conflicting parties. Explaining this complex process on theoretical grounds reveals such particular forms of understanding that bring us closer not only to a thorough conceptualization of mediation but to communication itself too. This paper encounters the units of mediation by means of a unique communication theory, namely the Participation Theory of Communication. This theory provides the categories by which this conceptualization can happen. Categories as the problem-solving agent, its capability for the identification and elimination of problems, the institutions and scenes of communication are related to the units of the mediation process in order to frame its specifics on communicational ground, therefore, to delineate the role of understanding in this process.
\end{abstract}

\section{Keywords}

mediation, Participation Theory, mediator, co-mediator, protocol 


\title{
MEDIÁCIÓ A KOMMUNIKÁCIÓ PARTICI- PÁCIÓRA ALAPOZOTT FELFOGÁSA (PTC) ${ }^{1}$ SZER I N T
}

\author{
Németh Viktor
}

A mediáció szemléletként ${ }^{2}$ és problémamegoldó protokollként is jellemezhető. Mint protokoll a mediáció a jog és a választott bíróság mellett a problémamegoldás és konfliktuskezelés egyik formalizált lépcsőfokának tekinthető. A jog eszközeit, szabályait a speciális tudás és felkészültség birtokában lévő választott bíróság még jól felismerhetően magában hordozza. A mediáció, mint protokoll azonban már jelentősen eltér a jogtól, olyannyira, hogy az ott hozott megállapodások ítéletbe foglalásakor annak megszületésének körülményeit a bíróság nem vizsgálja, csak tartalmának észszerüségét ellenőrzi.

A mediáció egy olyan kommunikációs folyamatként jellemezhető, ahol a felkészültségre maga az ágens is úgy tekint, mint a probléma felismeréséhez és/vagy megoldásához rendelkezésre álló ismeretre, más felkészültségére ${ }^{3}$ azonban nem. Ezek a mediáció folyamán válnak világossá az ágens számára, ekkor tudatosul benne, hogy birtokában van ezeknek az ismereteknek, készségeknek. Ez történhet annak hatására, hogy az ágens korábbi perspektívája a mediációs folyamat alatt megváltozik. Más perspektíva, más interpretáció felerősödésével a probléma felismeréséhez és megoldásához a korábbiaktól eltérő felkészültség válik szükségessé. Történhet mindez annak a hatására, hogy a mediációs folyamatban a saját igényei, szükségletei fogalmazódnak át, tisztulnak le a probléma kapcsán, és a megoldáshoz szükséges felkészültség megléte felismerést nyer az ágens által.

Annak, aki problémamegoldásra törekszik, a problémák kezeléséhez rendelkeznie kell a megfelelő mértékü felkészültséggel ${ }^{4}$, amellyel problémát ismerhet fel, illetve oldhat meg.

${ }^{1}$ A megnevezés alatt a Horányi Özséb féle kommunikációs participációs elmélet értendő (ld. Horányi 2007).

${ }^{2}$ Szemléletként a mediáció, mint konfliktuskezelési folyamat resztoratív vagy helyreállító szerepe hangsúlyos. Az átalakult, vagy megszünt egyensúlyi állapotot kívánja visszaállítani, vagy újraépíteni.

3 A felkészültség mint a Participációs Elméletben definiált terminus kerül alkalmazásra, mely szerint; „Az ágens iparkodásának hátterében egyrészt két olyan felkészültség, közelebbről alapkésztetés áll, amely minden ágenst jellemez: ennek értelmében törekszik megtenni mindent (ami lehetséges) a túlélésért és az élethelyzet (minőségének) - legalább - fenntartásáért ( $\mathrm{s}$ ez nem zárja ki a javítására vonatkozó esetleges törekvéseket sem); másrészt mindaz, ami e két alapkésztetésből leszármaztatható, mint az ágens szükséglete, illetőleg érdeke vagy éppen célja.” (Horányi 2007: 253)

${ }^{4}$ Felkészültség minden képesség, amely a probléma felismeréséhez és/vagy megoldásához szükséges. 
„A participációs felfogás a kommunikációt a problémamegoldásra való törekvéssel látja összefüggésben állni, mégpedig egyfelöl úgy, hogy a kommunikációt problémamegoldó tevékenységként tekinti; másfelől pedig úgy, hogy annak, ami a kommunikációt lehetővé teszi, (részben) egy sajátos, szerzett problémamegoldó felkészültség(készlet) a forrása." (Domschitz-Hamp 2007: 112).

A mediációs folyamatban az ágensek maguk aktivizálják erőforrásaikat, készségeiket, felkészültségüket a mediátor, illetve a folyamatban résztvevő ágensekkel folytatott kommunikáció hatására.

\section{A mediációban résztvevő ágensek}

A mediációba azok az ágensek kerülnek meghívásra, akik a vitás helyzetben döntési pozícióban vannak, valamint, akik a vitával kapcsolatos döntést befolyásolhatják akár implicit, akár explicit módon.

Amennyiben minden - a döntéshozatallal kapcsolatosan kompetens - ágens jelen van, mondhatjuk el, hogy az ágensek tekintetében a szükséges bemeneti feltételek teljesültek egy sikeres kimenetelü mediáció megvalósulásához. Ekkor van jelen minden olyan ágens egyazon fizikai térben és időpontban, aki hordozza azokat az ismereteket, tudást és felkészültséget, melyek szükségesek a mediáció folyamatához.

\subsection{Azágensek felkészültsége}

A mediációs folyamatba minden ágenst a mediátor hív meg. Ez akkor is igaz, ha valamely fél kezdeményezte a mediációt. Az ágenseknek rendelkezniük kell több különböző felkészültséggel ahhoz, hogy a mediációban részt vegyenek. Ezeket a felkészültségeket vagy készségeket a mediátor a mediáció előkészítése során ellenőrzi, hogy a mediációban kompetens részvétel valósulhasson meg. Abban az esetben, ha ezekkel a felkészültségekkel az adott időpontban nem rendelkezik az ágens, nem kerül meghívásra a mediációba. Amennyiben később megszerzi a hiányzó felkészültségeket - és még aktuális a mediáció - meghívásra kerül, vagyis a mediációs folyamat létrejöhet.

A következőkben azokat a - saját praxisomban összegyült tapasztalat alapján fölállított csoportokat taglalom, amelyekbe tartozó ágensek valamely felkészültségüket, készségüket hosszabb-rövidebb időre elveszítették, ezért nem kompetensek egy mediációs folyamatban.

Az ágenseknek rendelkezniük kell önálló döntéshozatali képességekkel. Nem lehetséges a részvétel olyan ágensek számára, akik tudatmódosító szerek hatása alatt állnak, függőségben vannak, még akkor sem, ha éppen a mediációs folyamat időpontjában ez nem így van. Nem vehetnek részt a mediációban azok az ágensek sem, akik valamilyen szenvedélybetegséggel küzdenek (például alkohol, játékszenvedély stb.), vagy pszichiátriai kezelés alatt állnak. Az ezekbe a csoportokba tartozó egyének nem lehetnek részesei a mediációs folyamatnak mindaddig, amíg a bipoláris tudatállapotuk nem változik meg tartósan, vagyis amíg nem gyógyulnak meg teljesen. Fontos megjegyezni, hogy a gyógyulás bekövetkezte után már részt vehetnek mediációban, tehát inkább lehet időbeni halasztásról, mint teljes kizárásról beszélni,

Megkülönböztetett csoport a kommunikációs kontroll nélküli ágenseké. Ebbe a csoportba több okból is tartozhatnak az ágensek. Az érzelmileg mélyen érintett, éppen a konfliktushelyzetüknek eszkalálódási szakaszában lévő ágensek gyakran nem tudják adekvátan megjeleníteni valós igényeiket, mert a túlzott emocionális telítettség miatt ${ }^{5}$ saját maguk sem lát-

5 A „túlzott” kifejezés azt jelöli, hogy az ágens agyában a limbikus rendszer dolgozza fel az emóciók szintjén a megélt eseményeket, így a tudatos kognitív folyamatok még nem tudnak elindulni. 
nak rá azokra. Kommunikációjukat olyan erőteljes emocionális töltöttség jellemzi, hogy nem képesek azt kontrollálni. Az ilyen állapotban lévő ágensek rendszerint - amennyiben foglalkoznak érzelmeikkel ${ }^{6}$ - néhány nap vagy hét elteltével mediációba vonhatóvá válnak. Amenynyiben nem adnak semmilyen megmutatkozási lehetőséget érzelmeik megélésének, kifejezésének, úgy - a neurobiológiai szabályszerüségeknek megfelelően - bezárkózással, az érzelmek elfojtásával védekeznek az őket ért érzelmi sérülésekre. Ennek folyománya a düh, harag, elutasítás - és egyéb, a kommunikációt destruktívan befolyásoló érzelem - egyre racionálisabb használata. Az egyének ezen csoportját a pszichológia a személyiségzavar fogalmával jelöli: a mediációk alkalmával leggyakrabban a borderline ${ }^{7}$ és az antiszociális személyiségzavarban ${ }^{8}$ szenvedők jelennek meg.

Egy további csoportba tartoznak azok, akik erőszakos cselekmények áldozatai-elkövetői voltak, és még a mediáció időpontjában is fennállhat az erőszakos cselekmény, vagy azzal való fenyegetettség - tehát szintén egyfajta függőség - lehetősége. Ez elsőre egyértelmünek tünik, azonban a mindennapi életben nem mindig tudja a mediátor elöre észlelni ezeket az eseteket. Ebbe a kategóriába leggyakrabban a családon belüli erőszak tartozik. A családon belüli erőszakot ma Magyarországon tabu övezi, vagyis nem beszélnek róla az érintettek, igaz nincs is megfelelően biztosított és társadalmilag kollektívan elismert színtere. Az áldozatok nem ismerik a helyzetből való kilépés útját, hallgatás és elfedés jellemzi a kommunikációjukat. Ezeket az eseteket akkor lehet a mediációban megjeleníteni és kezelni, ha a felek között helyre állt, vagy kialakult az egymástól fizikai, lelki, szellemi értelemben is független egyenrangú partneri állapot. Kívánatos, hogy a sértett megfelelő pszichés kezelést kapjon, mert például, ha valaki felnőtt, önellátó és még fizikailag sincs félni valója a sértettől, akkor is jellemzően fellép a poszttraumatikus stressz ${ }^{9}$ állapota, ami a korábban meglévő függő viszony tudati állapotát jeleníti meg, így kommunikációs szinten is meg fog mutatkozni az alá-fölé rendeltségi, félelem által vezérelt viszony.

Mindazok a személyek, akik nem szenvednek függőségben, pszichés betegségben, vagy erőszakos cselekménytől, résztvevői lehetnek egy mediációs folyamatnak. Ebben a folyamatban önként vesznek részt az ágensek, bármikor kiléphetnek belőle, semmilyen külső kényszer nem köti őket a részvételhez.

\section{A mediátor}

A transzformatív mediáció, mint az interperszonális mediációs evolúció legfejlettebb típusa úgy jellemzi a mediátort, mint pártatlan, elfogulatlan, semleges harmadik résztvevőt, akit a vitában résztvevő felek önként választottak. A mediátor nem ítél, nem dönt és nem ad tanácsot.

A mediátor olyan ágens a mediációs folyamatban, aki azt a tudást és felkészültséget hordozza, aminek révén a vitában álló felek képesek lesznek a sajátviláguk kifejezésére, meg-

${ }^{6}$ Az erős érzelmi terheltségen számos módszer tud hatásosan segíteni, ide tartozik minden olyan pszichológiai, önsegítő technika, ahol a figyelem fókuszában az érzelmileg terhelt személy ki tudja ventilálni azt az érzelmi többletet, amely akadályozza a hétköznapi kommunikációban. Ez az érzelmi többlet jóval jelentősebb kvantitással bír, mint amennyi egy mediációs ülésen kezelhető egy-egy érzelmi kitörés esetén. Ez utóbbiak ugyanis kifejezetten segítik a mediáció folyamatát. Ennek a konkrét ventilálási folyamatnak a segítésére, kísérésére számos rövidtávon, néhány hét alatt is rendkívül hatékony technika létezik, ilyen például az Újraértékelő Támogatás.

${ }^{7}$ Borderline személyiségzavar (Borderline Personality Dissorder BPD)

${ }^{8}$ Antiszociális személyiségzavar (Antisocial Personality Dissorder APD)

${ }^{9}$ Poszt traumatikus stressz (Posttraumatic Stress Disorder, PTSD) 
ismertetésére, a másik fél sajátvilágának befogadására, megértésére. (A sajátvilág itt a PTC szerinti sajátvilágot jelöli, azt „hogy milyenként ismeri fel az ágens mindazt, ami körülötte történik. Ugyanis például egy kijelentést ki lehet ragadni eredeti kontextusából, jól vagy rosszul idézni lehet stb., és ezzel új kontextusba, új színtérbe helyeződhet." Lásd DomschitzHamp 2007: 110)

\subsection{A mediátor, mint vezetö}

A mediátor, a résztvevő felek közül az egyetlen, aki átlátja a folyamatot, és lépésről-lépésre vezeti végig a feleket a mediációs protokollon. A mediáció különböző szakaszaiban különböző aktivitással, különböző kommunikációs technikával, végig proaktív, vezetői pozíciót tölt be (Wood 2004). A mediátor feladata és célja, hogy az ágensek képessé váljanak megmutatni, kifejezni a sajátvilágukat a mediációs folyamat minden egyes szakaszában. Számos verbális és nem verbális technikát alkalmaz, melyekben közös, hogy a résztvevők kompetenciáját, saját és közös erőforrásaikat erösítik meg. ${ }^{10}$

Az empowerment kifejezésnek korábbiaktól eltérö jelentését Bush és Folger kezdték el használni a transzformatív mediáció kapcsán. (Bush-Folger 2005) Értelmezésük szerint az empowerment nem erőkiegyenlítést vagy újraelosztást jelent, hanem képessé tevést, a saját értékek, erősségek, kapacitások érzékelését, észrevételét és tudatosítását a felekben, annak érdekében, hogy a bennük lévő megoldási eszköztárakat a legteljesebben tudják felhasználni. A résztvevő felek felkészültséggel rendelkeznek arra, hogy a lehető legjobb döntést hozhassák meg az adott helyzetben. A konfliktusban résztvevő ágensek tehát a sajátvilágukban található, a saját felkészültségüknek részét képező, a megoldás szempontjából releváns eszközöket használják. E készségek használatakor a probléma megoldásában résztvevő ágens a sajátvilágának kifejezéséhez - azaz a közös színtérbe helyezéséhez - az általa birtokolt legjobb eszközt, technikát alkalmazza.

Az empowermentnek vagyis a megerősítésnek a legfőbb célja, hogy az ágensek sajátvilága és a közös világ között a lehető legkisebb veszteséggel transzformálja az információkat. Ez igaz minden, a konfliktushoz tartozó, az ágensben megfogalmazódó, megjelenő szükségletre. Így a két világállapot közötti átjárásból adódó transzformer veszteség a meg nem értés kritikus szintje alatt tartható.

A mediátor a pozitív, támogató, biztonságos és diszkrét kommunikációs színtér megteremtésével, a felek felhasználható erőforrásainak megerősítésével egy, az ágensek számára eddig ismeretlen kommunikációs helyzetet teremt. A korábban megszokott, a másik felet negatívan megítélő, a múltbéli eseményekre összpontosító és ezek által egymástól szeparált pozícióban lévő ágenseket a jövőbeni közös együttmüködés, a megoldáskeresés felé vezeti lépésről lépésre. Ez a vezetés csak úgy valósulhat meg, ha a folyamat közben a mediátor követni tudja a felek valós idejü és tartalmi szükségleteikre vonatkozó igényeit. ${ }^{11}$ Ennek eredményeképpen az ágensek egymás saját olvasatát kölcsönösen megértve egy közös sajátvilágot hoznak létre. Az ily módon közösen kialakított sajátvilág magában foglalja a témakörre vonatkozó minden jelenlévő felkészültségét, ismeretét, tudását.

${ }^{10}$ A saját erőforrások megerősítését az angol szakirodalom az empowerment kifejezéssel jelöli.

${ }^{11}$ Leggyakoribb valós idejü igény, amit a mediátornak észlelnie kell, az érzelmi túltelítettségből fakadó un. „idő kérés”. Ez a mediáció bármely szakaszában megjelenhet. Ilyen például a közös múlt pozitív emlékeinek felelevenítése válás esetén, vagy az átszervezés körülményeinek átbeszélése egy munkahelyi mediáció esetén. Ilyenkor a tartalmi igény a szünet vagy a saját idő elrendelése (balcony effect), amelynek során a felek érzelmi szintje ismét elcsendesedik, mivel egy időre nem kap ingert, amely eltérítené az optimálistól a figyelmi szintet, amely a neocortex müködéséhez szükséges. 
Ezeken felül tartalmazza a kívánt szükségleteket és érdekeket is, amelyek az ágens számára kielégítendök a probléma eliminálásához. A közös felkészültségekhez minden érintett fél hozzáférhet (Horányi 2007). Ez eredményezi azt az új, közösen konstruált, közös sajátvilágot amely lehetővé teszi, hogy a résztvevő felek közösen definiálják azt a különbséget/változást, amely a konfliktust okozta közöttük. Az említett alapokon meghatározott probléma megoldására az ágensek saját vagy közös erőforrásaikat használhatják egymást kiegészítve, összehangolva. ${ }^{12}$

Ehhez első lépésként a párhuzamos gondolkodás (Bono 1994) eszköze nyújthat segítséget, mediációs kifejezéssel élve a „saját idő" ${ }^{13}$, amely során a felek megszakítás nélkül ismertethetik saját olvasatukat a problémával kapcsolatban. Ez az ismertetés túlmutat a tényszerü adatok reprezentálásán, megjelennek a mögöttes - vélt vagy valós - érzések, érzelmek, amelyek akadályozták a saját érdekek, szükségletek átlátható és biztonságos megjelenítését. Amennyiben az ágensek egyaránt ismertették sajátvilágukra vonatkozó saját olvasatukat, kölcsönösen lehetőségük nyílik a tágabb rálátásra és megértésre, a másik fél szempontrendszerének, gondolkodásmódjának megismerésére és figyelembevételére.

Ebben a szakaszban a felek a problémát egy másik perspektívából láthatják, így megváltozik a korábbi sajátviláguk aktuális problémával kapcsolatos része. Az empowermenten kívül ez a másik legfontosabb jellemzője a transzformatív mediációs protokollnak: a felismerés. A felismerés legfőbb ismertető jegye az a mozzanat, amikor a vitában résztvevő ágens képessé válik - rövidebb-hosszabb ideig vagy akár csak részlegesen is - a másik fél perspektívájából meglátni a problémát úgy, mint egy másik ember, annak minden érzésével (Bush-Folger 2005).

Ezeket a gondolatokat, érzéseket - ismereteket, tudásokat - az ágensek eddig intencionális alapokon nyugvó hiedelmekkel pótolták. Az ágensek között megosztott konkrét megközelítések eliminálják a problémával kapcsolatos emocionális megközelítést.

A saját világ feltárása által megismerni a másik fél érzéseit, sajátvilágát megnyugvást jelent, melynek hatására az ágensekben a félelem által kiváltott neurobiológiai folyamatok leállnak, vagy lényegesen lecsökkenek, és ez az, ami lehetővé teszi, hogy a racionális döntéshozatalhoz szükséges folyamatok elindulhassanak (Bogacz-Lack 2010).

A megismerést követően már kizárólag az ide vonatkozó tartalmi rész képezi a vita alapját, így nem a másik fél, hanem a megoldandó probléma kerül a fókusz középpontjába. Ez a mediátor szemszögéből a legfontosabb fordulópont. Amennyiben létrejött, érzékelnie kell a beállt változást és alkalmazkodnia kell hozzá.

Abban a szakaszban, amikor a felek már közösen dolgoznak a probléma megoldásán, mert sajátvilágaikat megosztották, és egymás igényeit kölcsönösen elismerik, a mediátor a figyelem teljes megörzésével, de egyre többször kerülhet követő pozícióba. Ez azért lehetséges, mert az ágensek emocionális aktivitása lecsökkent, helyét pedig akár a saját, akár a közös múltból ismert közös konstruktív kognitív ${ }^{14}$ együttmüködés veszi át. A kognitív szakaszban is szükségessé válhat a vezetési aktivitás igénye, azonban a konkrét, racionális javaslatok össze-

${ }^{12}$ A mediátor mint vezető segít eljuttatni a feleket a közösen konstruált sajátvilághoz. De fontos megjegyezni, hogy a mediátor nem része ennek a sajátvilágnak.

${ }^{13}$ A mediációs folyamatot az egyes iskolák 4-7 lépésre bontják. A négy lépést Judd és Kenny, valamint James és Brett publikálta (Judd-Kenny 1981), (James-Brett 1984), a hét lépést Santa Maria dolgozta ki jogász kollégáival (Santa Maria-Gregg 1997). A második szakasz minden esetben az ágensek saját ideje, ahol a többi jelenlévő beleszólása nélkül mondhatja el a saját perspektívájából az adott konfliktushoz kapcsolódó meglátásait.

${ }^{14}$ Itt: gondolkodáson alapuló. 
rendezése már egy más minőségü, megszokott vezetői tevékenységet implikál. Ebben a szakaszban többnyire egy rendszerező, időről időre összefoglaló minőségében jelen levő vezetőre van szükség, aki hagyja a feleket egymással kommunikálni a már korábban kialakított csatornán keresztül.

A mediátor felkészültségei közé tartozik az idő megfelelő kezelése is, amiben nem csak az ülésen belüli időkontroll, de a mediációs folyamat időbeni megtervezése is nagy jelentőséggel bír. Amennyiben az üléseket egymáshoz közel tartja meg (a gyakorlati tapasztalatok alapján öt napnál közelebb), úgy a felek nem vagy csak részlegesen képesek feldolgozni azoknak az érzelmi és információs tartalmát. A tapasztalatok alapján két mediációs ülés között eltelt ideális idő az egy hét. Az ülések között két hétnél hosszabb szünet elteltével túl sok információ merül feledésbe, és sokkal nagyobb az esélye az ülés előtti állapot és a hozzá tartozó - rendszerint destruktív - gondolkodásmód visszaállásának.

\subsection{A mediátor felkészültségei}

A mediátornak többrétü felkészültséggel kell rendelkeznie. A legfontosabb felkészültség az önismeret minél magasabb foka (Herman et al. 2001). A mediátor a különböző önismereti kurzusokon, tanfolyamokon ${ }^{15}$ megtapasztalt saját élményen keresztül képes a saját emocionális és kognitív müködését lépésröl-lépésre tudatos szinten megfigyelni és megismerni. Fogalmazhatunk úgy is, hogy ezek az évekig tartó önismeretet adó kurzusok az egyén sajátvilágának tudatos megismeréséhez, a sajátvilág határainak megtapasztalásához és a későbbiek során azok felismeréséhez segítik hozzá a mediátort. A mediátor ezen felkészültségek birtokában - a sajátvilág megmutatkozásának tekintetében - tud hiteles lenni a mediációs ülésen. Hitelesség alatt azt értem, hogy a szándékosan mutatott verbális és nonverbális kommunikáció nem vagy csak nagyon kis mértékben tér el a vitában résztvevő felek által érzékelttől. Ez a fajta hitelesség a felekben bizalmat és biztonságérzetet kelt, ami azért kulcsfontosságú, mert a felek negatív attitüddel, destruktív gondolkodással és bizalomvesztett állapotban érkeznek meg az első mediációs ülésre.

Amennyiben a mediátor hiteles a résztvevő felek számára, úgy kiépülhet az a bizalmi légkör, amelyben mint a folyamat vezetője elfogadottá válik. Fontos distinkció, hogy az irányítói szerepkör a bizalmi légkör nélkül is megvalósul. Ezt a fajta hitelességet azonban nem lehet megjátszani, mert a nonverbális kommunikációból kiderül, és anélkül, hogy ez a felekben artikulálódna, a tudatosság szintjén mégis hatást gyakorol.

Amennyiben a mediátor rendelkezik önismerettel, azaz a sajátvilága müködésének ismeretével, úgy ismerős lesz számára a mediációban résztvevő felek sajátvilágának megmutatkozása is. Azaz képes felismerni, hogy a felek sajátvilága mikor mutatkozik meg a közös mediációs sajátvilágban, vagy ha nem tud megmutatkozni, a mediátor felismerheti, hogy mi

${ }^{15}$ A gyakorlati tapasztalatok azt mutatják, hogy az egyéni terápia, családállítás, pszichodráma, mozgásterápia, újraértékelő támogatás (reevaulation councelling) mind olyan folyamatok, amelyek során a résztvevők a kapott visszajelzések alapján nem csak egy adott problémájukat tudják jobban megoldani, de önismeretük, önértékelésük és leginkább önmaguk elfogadása változik meg nagymértékben és pozitív irányba. Ezek a folyamatok ahhoz segítik hozzá a mediátort, hogy saját múltjában a pszichés eredetü félelmeket, rossz emlékeket, gyászt, tehát a sajátvilág azon részeit, amelyeket gyakran magunk elött is tabuként kezelünk, magabiztosan kezelje, és legyen saját élmény a pozitív irányú változásra. Ezek a tapasztalatok elengedhetetlenek ahhoz, hogy a mediátor ne csak kognitív szinten, hanem az emóciók szintjén is képes legyen magabiztosan, hitelesen, kellő figyelemmel, érzékenységgel és cizelláltsággal kommunikálni. Ez azért fontos, mert ez az a dimenzió, ahol a legtöbb kommunikációs elakadás forrása található; ha ebben a dimenzióban a mediátor nem képes jól kommunikálni, nem tudja az ágensek sajátvilágának megmutatkozását biztonságosan segíteni. 
az, ami még szükséges a megmutatkozáshoz, vagy a már megmutatkozott sajátvilág egy másik aspektusának megmutatkozásához. Ezen képesség birtokában tud a mediátor olyan kommunikációs technikát alkalmazni, amely elősegítheti az előbbre lépést a sajátvilágok megmutatkozása terén (Herman et al. 2001).

Azok után, hogy megteremtette a megfelelö környezetet a sajátvilág megmutatkozására, a mediátor célja az lesz, hogy mindez megmutatkozásra kerüljön a közös sajátvilágban is minden résztvevő fél részéről. A résztvevők egymás sajátvilágának megismerési folyamatát egybekötik a sajátjuk fokozatos feltárásával, feloldásával. ${ }^{16}$ Ez a közös sajátvilág konstruálásának folyamata.

\subsection{A ko-mediátor}

A mediátori képességek közül az egyik legfontosabb, hogy a mediátor felismerje szakmai felkészültségének, tudásának és lehetőségeinek határait egy adott mediációs megkereséssel kapcsolatban. Erre rendszerint az elökészítési szakasz során van lehetőség, amikor az ügy részletei és szereplői feltérképezésre kerülnek. Egy felkérés során a következő választási lehetőségek adódnak a mediátor számára:

a. A mediátor elvállalja az ügyet.

b. A mediátor nem vállalja el az ügyet, mert:

- Nem tartozik a mediáció hatáskörébe.

- A mediátor személyes összeférhetetlenség miatt nem vállalja. (P1. rokonától érkezik a felkérés.) Rendszerint egy másik mediátorhoz kerül az ügy.

- A mediátor olyan élethelyzetben van, hogy nem tudja elvállalni személyes érintettség miatt. (Pl. a mediátor válik és nem vállal el egy válási mediációt.) Rendszerint egy másik mediátorhoz kerül az ügy.

c. A mediátor az ügy típusa miatt bevon még egy mediátort, akivel együtt vállalja el az ügyet. Ezt hívják ko-mediációnak ${ }^{17}$.

A ko-mediáció elsősorban a párkapcsolati és közösségi mediációk során alkalmazott eljárás. Ennek lényege, hogy nem egy, hanem két mediátor vesz részt a folyamatban.

Itt a két ellentétes nemü mediátor jelenléte hordoz többletfelkészültséget és teremt egyensúlyt. Nagyon erős egyensúlyteremtő és biztonságnövelő szerepe van egy válófélben lévő pár esetében, mert pont abban a dimenzióban, amiben a probléma megmutatkozik (nőférfi) kapcsolatrendszer, van kiegyenlítődés, egyensúly, egyik fél sem marad egyedül. ${ }^{18} \mathrm{~A}$ komediáció alapvetően a már gyakorlattal rendelkező mediátoroknak ajánlott. A mediáció ezen típusa során még egy kollégára is figyelni kell, illetve kölcsönösen alkalmazkodni kell a mediátoroknak egymáshoz. Az erőviszonyok egy ilyen mediációs ülés során kiegyenlítődnek: rendszerint az egyik mediátor vezeti a protokoll szerint az ülést, így a másiknak több ideje marad a dinamikára és az adott kommunikációs technikák alkalmazására figyelni. Továbbá több figyelem jut a felekre is, amit párkapcsolati és nagyobb stresszel járó üzleti mediációk esetén a felek nagyra értékelnek és maximálisan ki is használnak.

\footnotetext{
${ }^{16}$ Rendszerint így érzik a legbiztonságosabbnak, és így jutnak el a legkönnyebben a számukra szükséges megfelelő szintre, ami a közös sajátvilág konstruálásához szükséges.

${ }^{17}$ Angolul co-mediation.

${ }^{18}$ Ez a folyamat elején nem tudatosul a felekben, de a mediáció sikeres lezárása után kifejezetten pozitívan értékelik és kiemelik a nemi egyensúly szerepét.
} 
A másik leggyakoribb típusa a ko-mediációnak, amikor a mediációban résztvevő felek létszáma több mint, amennyit a mediátor saját megítélése szerint biztonságosan és kellö figyelemmel tud kezelni. Ez a gyakorlati tapasztalatok szerint négy-öt főnél kezdődik. Itt a felek csoportszerü viselkedése, valamint a megnövekedett ülésidő ${ }^{19}$ által okozott megnövekedett igénybevétel teszi szükségessé a két mediátor jelenlétét. Ez a közösségi - iskolai, települési, stb. - mediációk során bevett gyakorlat. ${ }^{20}$

Ko-mediációnak nevezik azt a szakmai gyakorlatnak tekinthető tanulási-tanítási fázist, amikor a kezdő mediátor részt vesz az első mediációs ülésén. A kezdő mediátornak a mediációs folyamat levezetéséhez szükséges technikai tudás és felkészültség a birtokában van. A valós helyzetben való jó gyakorlat azonban még nem. A jó gyakorlatot itt az a tapasztalatból származó tudás és ismeretanyag jellemzi, amely a mediátor saját müködésére vonatkozik. Arra, hogy hogyan reagál a különböző helyzetekre, például erős érzelmi kitörésre, sírásra, kiabálásra. Milyen szinten képes felismerni a mediáció során megjelenő kommunikációs nehézségeket, csapdahelyzeteket, például játszmázást (Berne 2002). Az ilyen ko-mediáció során a kezdő mediátor a sajátvilágának mediációs ülésre vonatkozó megnyilvánulásait tanulja. Ezt biztonságosan megteheti, mert a gyakorlott mediátor ebben az esetben egyértelmüen vezeti az ülést. Kontroll alatt tartja a folyamatokat, ügyel az időre, és még a kezdő mediátorra is, akit ilyenkor a sajátvilágának megfigyelésén kívül a mediációs folyamat figyelésével is megbíznak, valamint azzal, hogy rögzítse a föbb adatokat - jegyzőkönyvezzen, és adjon visszajelzést, ha szükséges.

\subsection{A mediátor mint semleges, pártatlan participátor}

Semleges és pártatlan mediátor de jure igen, de facto - az interperszonális kommunikációból fakadóan - nem létezhet. A szabályok értelmében a mediátor nem lehet érintett a mediációs folyamat ügyében, nem lehet megelőzőleg - privát ${ }^{21}$ - kapcsolatban a felekkel.

A szabályozás itt is a látható racionális világra vonatkozik. A mediátor sajátvilágból más és más reakciót, érzéseket váltanak ki az egyes ügyek (pl. válás) és az azt interpretáló ágensek személyisége vagy éppen kommunikációs stílusa.

A mediátor sajátvilágában megtalálható emlék vagy tapasztalat által kiváltott reakció különböző mértékben befolyásolja elfogultságukat. Ennek a milyensége és mértéke attól függ, hogy a mediátor mint ágens milyen mértékben képes ezeket az emlékeket tudatos szintre hozni és a mediáció közben ezekre figyelmet fordítani. Vannak emlékek, amelyek, még ha régen történtek is, mindig a tudatunk felszínén maradnak, így könnyen kezelhetjük öket ezen a szinten. Ebben az esetben a mediátornak könnyü észrevenni a benne elindult, de az adott szituációban nem releváns érzéseket, érzelmeket. Ilyenkor elég ezt tudatosítani és az ülés végéig, azaz néhány óráig figyelni, hogy ne erősödhessen fel ez az érzés és ne befolyásolhassa a mediátori tevékenységet. Minél tudatosabban van jelen a mediációs folyamatban a mediátor, annál biztonságosabban tud a sajátvilág megmutatkozásához szükséges feltételeket, körülményeket implikálni a résztvevő felek számára.

${ }^{19}$ A bevett három óra helyett néha négy-öt órát is igénybe vesz egy közösségi mediáció.

${ }^{20}$ Nagyobb létszámok esetén 3-5 fő is végezheti a mediációt: előkészítő, ülést levezető mediátor, két jegyzökönyv írói feladatokat ellátó mediátor.

${ }^{21}$ Lehetséges, hogy valaki egy korábbi mediációból ismeri a közvetítőt, és a második esetében is ugyanazon mediátorhoz fordul néhány évvel később. Természetesen a mediációs ülésre való felkészítés során erről a másik felet tájékoztatni kell. 
Az ellenérzések mellett az ágenssel történő szimpatizálás is eltéríti a teljes neutralitástól. Az emberi kapcsolatokban intencionális alapokon néhány másodperc alatt megítéljük azt, aki belép az ajtón. Ez a mediációban fokozottan igaz, hiszen az előkészítés többnyire telefonon történik, és így az első mediációs ülés alkalmával pillantja meg a mediátor a résztvevőket és viszont. A pszichológia ezt a jelenséget személypercepciónak nevezi.

Frith-Frith (2007) a szociális kogníció fogalmán többek között azon interakciókat érti, amelyek által létrejöhet a kommunikáció egy adott faj egyedei között. A legfontosabb ingerterület, amelyet a kommunikációs folyamatban résztvevő partnerek a leggyorsabban ellenőriznek és a visszajelzés forrásaként használnak, az az arc területe. A folyamatos vizuális kontrol által innen tudjuk a legrövidebb idő alatt azonosítani a másik fél aktuális érzelmi viszonyulását, figyelmének a fokát, az adott személyhez vagy témához való hozzáállását, stb.

A fenti értelmezés alapján a mediátor célja a tudatosságra törekvés annak érdekében, hogy minél inkább meg tudja örizni figyelmét a felek irányában, és háttérbe tudja helyezni - a mediációs ülés végéig - a saját korábbi pozitív vagy negatív emlékeit, érzelmeit az üggyel kapcsolatban.

\section{A mediáció, mint intézményesült protokoll}

„A PTC keretében az intézmény olyan, a problémamegoldás szempontjából tekintett többlet-felkészültségként definiálódik, mely a közösség tagjai számára egyaránt elérhető, és nem az adott közösségben, társadalomban érvényesnek tekintett viselkedési szabályok rendszereként (...). Az intézmény tehát tematikus mezőként értendő, mely a közösség által osztott többlet-felkészültségben többé-kevésbé jól kijelölhető (bizonyos többlet-felkészültségek az egyik tematikus mezőhöz tartoznak, míg mások egy másikhoz). Egyfajta horizontként, amelyben a világ hasonlóképpen mutatkozik meg a közösséget alkotó ágensek számára, mintha ugyanolyan vagy hasonló perspektívából tekintenének rá. Vagyis az egyik intézmény által körülhatárolt többlet-felkészültség egy bizonyos módon strukturálja a világot, míg egy másik felkészültség egy másik módon. A különböző intézményekben különböző (és azonos) felkészültségek vannak együtt." (Pete-P.Szilczl 2007: 42)

A mediáció folyamatának intézményesülése participációs értelemben a joghoz - mint problémamegoldó intézményhez - viszonyítva rendelkezik többletfelkészültséggel. Ez a többletfelkészültség a kommunikációs csatornák széles körének szakszerü alkalmazásában jelenik meg elsődlegesen. A probléma megoldásához nem egy univerzálisan meglévő általános - az ágens sajátvilágával kapcsolatban nem álló - protokollt használ. A mediációs protokoll a problémafelismerést és problémamegoldást úgy strukturálja, hogy a kommunikációs csatornák legszélesebb spektrumát felhasználva az ágensek sajátvilágát valós idejü ${ }^{22}$ és transzformációs veszteség nélkülii ${ }^{23}$ interakcióba vezeti. A mediáció többlet-felkészültséggel bír, a probléma megoldását azzal segíti elő, hogy az ágensek kommunikációs - kifejezési lehetőségeit mind a hétköznapitól, mind a jogi megoldásoktól eltérően használja. Ez ad lehetőséget arra, hogy az ágensek a vágyott sajátvilág állapotukat felismerjék és artikulálják a me-

${ }^{22}$ A valós idő a mediáció idejére vonatkozik, az ágensek sajátvilágának akkori állapotával dolgozik, a jövőben megvalósítható megoldásokra fókuszálva, figyelembe véve a múltbéli állapotokból származó hatásokat.

${ }^{23}$ Transzformációs veszteség a sajátvilágból a közös világba való átalakítást, átfordítást jelöli. Ez a veszteség minden egyes transzformációs aktusnál fellelhető, de a mediációs protokollra jellemzően olyan alacsony a folyamattal járó veszteség, hogy az érdemben nem befolyásolhatja a folyamat kimenetelét. 
diációs színtéren. A sajátvilágok közös világban való megmutatkozását egy irányított, több szakaszból álló folyamat (protokoll) segítségével idézhetjük elö. Ez a folyamat intézményesült a törvény által önálló problémamegoldó rendszerként. A jog mint problémamegoldó intézmény először saját rendszerén belül alkalmazta, amikor az ágensek a jogi intézmény terminusait a jog szakértőivel (ügyvédekkel, jogászokkal - vagyis az intézményi többlettudás hordozóival) koalíciót alkotva olyan patthelyzetet teremtettek, ${ }^{24}$ melynek feloldására a jognak nem volt eszköze. A mediáció önálló protokollként is müködő intézményként van a törvényi szabályozásba iktatva. A bíróság nem vizsgálja a problémamegoldás folyamatát és semmilyen más természetes vagy jogi személy számára sem teszi azt lehetővé: a Közigazgatási és Igazságügyi Minisztérium által jegyzékbe vont mediátorok által szignált mediációs megállapodások magánokiratok, ítéletbe foglalhatók. ${ }^{25} \mathrm{~A}$ mediátorok a mediációs folyamat után az ügygyel kapcsolatban nem citálhatók jogi folyamatba, nem idézhetőek meg jogi eljárás keretében.

A mediációs protokollnak az a strukturált kommunikációs - hiánypótló - többlettudás jelentette az intézményesülési lehetőséget, amely más problémamegoldó rendszerek esetében hiányzott. Ez a többlettudás a mediátor által vezetett kommunikációs folyamat során válik hozzáférhetővé az ágensek számára.

A mediációs protokollt a különböző mediációs mühelyek négy-hét szakaszra osztják. Rendszerint a kevesebb érzelmi területet érintő eljárások vonnak össze több lépést. A négylépéses módszert Charles Judd és David Kenny (Judd-Kenny 1981) publikálta elöször. A hét lépést Santa Maria dolgozta ki jogász kollégáival (Santa Maria-Gregg 1997). A teljes spektrum részletes bemutatása érdekében mind a hét lépés ismertetésre kerül.

A mediáció első szakasza ${ }^{26}$ minden esetben az ülés megnyitása, a folyamat szabályainak ismertetése. Ebben a szakaszban a mediátor kötelessége ismételten elmondani a résztvevőknek, hogy az önkéntesség az eljárás végéig fennáll, a folyamatot minden egyes pillanatban a mediátor vezeti, ezt a felek tudomásul veszik. Közösen kerül meghatározásra az ülés időtartama, a szünetek gyakorisága és hossza, valamint a telekommunikációs eszközök kizárása. Az ágensek kitöltik a mediációs kérelmet a mediátor(ok) felé, a mediátor(ok) pedig a folyamatra vonatkozó titoktartási nyilatkozatot.

A második szakasz az ágensek problémájához tartozó saját olvasat ismertetése. Ezt a szakaszt szokás saját időnek is nevezni, mert az ágensek itt érdemben nem szólhatnak bele a másik fél saját olvasatának ismertetésébe; amennyiben reagálni szeretne a másik fél éppen elhangzott mondandójára, úgy lejegyzi és a saját olvasatának ismertetésekor ismerteti annak tartalmát. Ebben a szakaszban az ágensek egymás közötti kommunikációs állapotától függően vagy csak a mediátornak, vagy esetleg mediátoroknak és a másik ágensnek is meséli a saját

${ }^{24}$ A végtelenségi elhúzott üzleti vagy magánéleti (jellemzően válási) pereskedések olyan mértékben terhelték/terhelik le a bírósági rendszereket, hogy az ítélet meghozatalakor a megoldandó helyzet már egyáltalán nem aktuális, nem áll fenn. Ezt a folyamatot a bíróság nem tudja megakadályozni, feloldani. Egyetlen megoldásként a jogi kereteken kívüli rendszereknek adja át a teret alternatív vitarendezési eljárásoknak, melyek közé tartozik a mediáció is.

${ }^{25}$ Amennyiben teljes körü megállapodás születik, sok esetben a bírósági végzés pro forma szerepet tölt be.

${ }^{26}$ Kommunikációs folyamatot vizsgáló perspektívából magát az ülést megelőzi a kapcsolatfelvétel, amelyet az ágensek valamelyike kezdeményez. Ezt követi a felekkel történő együttes vagy - jellemzően - külön felkészítés, a mediációs folyamat ismertetése az ágensekkel, az ügy, valamint az ágensek alkalmasságának felmérése. Amennyiben mind az ágensek, mind a mediátor(ok) vállalják a mediációt, azt megelőzően minden esetben a lehetőségekhez mérten a legjobb fizikai színteret kell megteremteni a mediációs eljáráshoz; ezt nevezzük nulladik lépésnek is. 
olvasatot. ${ }^{27}$ A második szakaszban a mediátornak minden a probléma megoldása szempontjából fontos információt ${ }^{28}$ össze kell gyüjtenie, hogy a későbbi információhiányból fakadó félreértések, tévedések megelőzésre kerüljenek. A mediátor feladata az ágensek sajátvilága problémáival kapcsolatos érdekeik megmutatkozásának segítése, saját erőforrásainak, készségeinek megerősítése. A megerősítés és elismerés ettől a szakasztól a folyamat végéig alkalmazandó.

A harmadik szakaszban a felek listát készítenek a megtárgyalandó témákról. Ezeket a témákat elöször racionalizálás nélkül jelölhetik meg, amelyet aztán leszükítenek és rangsorolnak fontossági sorrend szerint, közös megegyezéssel. A megtárgyalandó témák köre változhat - egyaránt csökkenhet és bővülhet a későbbiekben -, amennyiben az ágensek egyöntetü véleménye szükségessé teszi.

A negyedik szakaszban a felsorolt témák megtárgyalásra kerülnek az ágensek által meghatározott sorrendben. Ebben a szakaszban a mediátor a szükséges megerősítéseken kívül nem tesz vezető lépéseket, hanem hagyja, hogy a felek a sajátvilágaik egy részét közössé formálják. Ebben a diszkusszióban sokféle megoldás felbukkanhat, ezek keresése a problémamegoldó mediáció esetén fontos, a transzformatív mediáció esetén viszont nem. Ez utóbbi esetben a megváltozott nézőpont által kiváltott reakciók sajátvilágra gyakorolt hatása számít. Azaz a más perspektívából megmutatkozó felismerés révén az ágens sajátvilágából származó felajánlások mentén racionalizálódik a megegyezés. Az eredmény tekintetében ez a különbség érzékelhetetlen marad. ${ }^{29}$

Az ötödik szakaszban a megállapodás kidolgozására, konkretizálására kerül sor a résztvevők között, itt a mediátornak a feladata annak ellenőrzése, hogy minden jelenlévő ugyanúgy értelmezze az egyes témákhoz tartozó megállapodást.

A hatodik szakaszban a felek által kidolgozott megállapodásokat a mediátor írásban rögzíti. Az írásba foglalt megállapodás aláírása előtt a felek számára biztosítani kell annak átolvasását, ellenőrzését, mert a gyakorlati tapasztalatok szerint mindig van javításra javasolt rész valamelyik fél által. A megállapodást minden résztvevő aláírja, és annyi eredeti példányt kell készíteni, ahányan részt vettek a mediációs folyamatban.

A hetedik szakaszban a mediációs folyamat lezárására kerül sor. Ismételten ismertetik a megállapodás sorsát. ${ }^{30} \mathrm{~A}$ mediáció sikerétől függetlenül a mediátorok elismerik a résztvevő felek mediációba fektetett munkáját, és összegzik az előrehaladást, az elért változást.

Magyarországon a folyamat a közép-európai mediációs szokásokhoz illeszkedve 3 órás ülésekből áll, amelyeknek száma ügytípustól függően egy és öt között változik. Egy válási

${ }^{27}$ A mediáció első szakaszában, amíg nem alakul ki a közös kommunikációs csatorna, hatékonyabb, ha a felek a mediátor felé fordulva ismertetik a saját olvasatukat. A folyamat későbbi szakaszaiban az ágensek már könnyebben kommunikálnak a másik féllel a kezdeti zavar elmúlása után.

${ }^{28}$ A „fontos információ” kifejezés nem a probléma egyes tartalmi részleteit, argumentumait jelöli, hanem az ágens számára a sajátvilágának és a probléma felismerésének/megoldásának szempontjából jelentőséggel bíró momentumokat. Például, ha az ágensnek a korábbi lakás érzelmi kötődést jelent, akkor ez kerül fókuszba, és nem a tulajdoni lapon szereplö pontos négyzetméter szám.

${ }^{29}$ A problémamegoldó típusú mediációk esetén a felek csak a lehetséges megoldásokat keresik, ajánlják fel. A sikeres megegyezés ezek után kihathat a sajátvilágukra, mintegy interiorizálódhat pozitív problémamegoldási mintaként. Transzformatív mediáció esetén a sajátvilág változik meg a másik ágens elfogadásának tekintetében pro és kontra. Így a két, megváltozott sajátvilággal bíró ágens alkot egy megváltozott közös sajátvilágot, ahol megtalálják a számukra megfelelő megoldást.

${ }^{30}$ Az ügy típusától függően kerülhet a megállapodás a felekhez, akik betartják azt, és csak kérdéses helyzetekben veszik elő újra, vagy kerülhet a bíróságra is, ahol a bíró ítéletbe foglalja a mediációs megállapodást. 
mediáció a tapasztalatok szerint 3-4 alkalmat vesz igénybe - ez körülbelül egy hónap, ha hetente kerülnek az ülések megtartásra. Az érzelmi érintettség magas foka miatt ennyi időre jellemzően szükségük van a feleknek. A kevésbé mély emocionális töltetü ügyek esetében 1-3 alkalom is elégségesnek bizonyult.

\subsection{A mediációs színtér}

A mediáció magyarországi törvényi szabályozása ${ }^{31}$ lehetőséget adott arra, hogy a mediációs protokoll ne csak civil keretek között lefolytatott privát aktusként, hanem a jog intézményi ${ }^{32}$ rendszerében is helyet kapjon (Horányi 2007).

A színtér fogalmát a PTC értelmezésében használom.

„A színtér nem magában áll, hanem mindig ágenshez kötött, és az ágens mindig színtérhez kapcsolódik. Ágensek megnyilvánulásaikban mutatkoznak meg ágensként. Színtér tehát az a hely, ahol az ágens ágensként megnyilvánul. (...) Amennyiben tehát a színteret konstituálja az ágensek felkészültsége, akkor a színtér leírását mindig ágensek felkészültségére hivatkozva lehet megadni. Ebből következően különböző felkészültségtípusok különböző színtértípusokat eredményeznek. Nevezzük összefoglalóan színtérnek mindazokat a körülményeket, amelyek valamely ágens számára meghatározzák egy adott esemény lehetséges „interpretációit”. Ez az értelmezés nem a megnyilatkozás körülményeire hivatkozik, hanem lehetséges „,interpretációira”, vagyis arra, hogy milyenként ismeri fel az ágens mindazt, ami körülötte történik. Ugyanis például egy kijelentést ki lehet ragadni eredeti kontextusából, lehet jól vagy rosszul idézni stb., és ezzel új kontextusba, új színtérbe helyezödhet." (Domschitz-Hamp 2007: 110)

A jog mint intézmény saját müködési logikájával sok konfliktus esetén valóban konstituálja a színteret ágensei (bíró, ügyész, ügyvéd, bírósági szakértők, tanúk) felkészültségével, és ez a színtér fizikai síkon maga a bírósági tárgyalóterem, problémamegoldó protokoll tekintetében pedig maga az eset bírósági tárgyalása. Ezekben az esetekben az ágensek felkészültsége magas az intézményhez tartozó nyelvi, logikai elemek tekintetében.

Vannak esetek azonban, amikor ágensként nem a jogi képviselő nyilvánul meg, hanem az a személy, akinek az érdekeit képviselte a jog intézményi rendszerében felkészültsége és tudása szerint a legjobban. Ezeknek a személyeknek nincs felkészültségük a joghoz tartozó terminusokból, viszont bizonyos esetekben a jogi képviselőjük nem tud helyettük nyilatkozni. Ilyen például az a helyzet, amikor a válóper esetén a gyermek elhelyezésben nem tudnak megegyezni a felek. Ebben az esetben a bíró direkt a feleknek tesz fel kérdéseket, a jogi képviselöik számos alkalommal egyeztetnek, azonban nem történik elörelépés. ${ }^{33}$ Ezekben a helyzetekben a jogi protokoll a jogi képviselők bevonásával (a gyakorlatban a felek nélkül) történő egyeztetést alkalmazza, mint a tovább lepést elősegítő lehetőséget. A jogi protokoll által

${ }^{31}$ Polgári peres eljárásokban 2002-ben, büntető peres eljárásokban 2007-ben született törvény a mediáció szabályozásáról.

32 „A társadalomban kialakult rendszer, forma, szokás; intézménynek nevezzük a társadalomban érvényesülő, az egyének cselekedeteit irányító vagy befolyásoló, illetőleg behatároló szabályokat, írott vagy íratlan törvényeket és ezek rendszereit; szintén intézmény szóval jelöljük ezen szabályok betartását biztosító mechanizmusokat (szervezetek, társadalmi értékek, szankciók); egyes intézmények csak szabályok szintjén léteznek (mint például a jogszabályok).” (Horányi 2007)

${ }^{33}$ Ezekben az esetekben nyilvánvaló mind a jogi képviselők, mind a bíró számára, hogy a felek a legritkább esetben vitatkoznak a gyermekelhelyezésen, azt csak egy ürügynek használják fel más rejtett - rendszerint közöttük feszülő személyes - konfliktus miatt. 
nem érzékelt probléma azonban nem oldódik meg, mert nem a megfelelő színtéren van artikulálva, úgy is mondhatjuk, hogy a vitában álló felek nem tudnak ágensként megmutatkozni a bírósági színtéren, mert a felkészültségük nem ezt a színteret konstituálja. Ezekben a helyzetekben van lehetőség arra, hogy az ügy mediációs folyamatba kerüljön a folyamat elöremozdításának érdekében.

„Amennyiben a színtér fogalmán mindazokat a körülményeket értjük, amelyek valamely ágens számára meghatározzák egy adott esemény lehetséges »interpretációit $\aleph^{34}$, úgy az értelmezés nem a megnyilatkozás körülményeire, hanem arra vonatkozik, hogy az ágens milyenként ismeri fel mindazt, ami körülötte történik." (Domschitz-Hamp 2007: 110)

Ebben az értelmezésben az ágens nem csak a probléma hordozója, megjelenítője, hanem a megoldásába aktívan bevont résztvevő. Ez azért kiemelkedően fontos, mert a mediációs folyamatnak alaplogikája, hogy a folyamatban résztvevő ágensek saját értelmezésükben és felismeréseikben való változás által jutnak el a probléma megoldásához. Amennyiben a probléma nélküli világállapot (Wpn1), a problémaként érzékelt világállapot (Wp1) és az ismételt probléma nélküli világállapot (Wpn2) logikai vonulatot vesszük alapul, ${ }^{35}$ úgy egyértelmü, hogy csak és kizárólag akkor valósulhat meg mindez, ha a folyamatot megvalósító, kivitelező ágensek részét képezik a folyamat minden egyes lépésének. Amennyiben kirekesztjük vagy szeparáljuk a probléma felismerésétől bármelyik ágenst a folyamatban, és csak az új probléma nélküli világállapot (Wpn2) megoldásához szükséges feltételek, lépések elvégzését szabják meg számukra, jelentős részüket nem tudják végrehajtani.

A kirekesztés látszólag nem történik meg semmilyen szinten, azonban, a jog mint intézmény a már korábban kifejtettek szerint az ítéletben a megszokottól való eltérést szankcionálja, amit tovább erősít az idők folyamán kialakult saját terminológiája, nyelvezete. ${ }^{36}$

A problémában résztvevő ágensek emocionális megnyilvánulásait, amelyeket ma leginkább a kommunikáció, a pszichológia, a neurobiológia nyelvén magyaráz a tudomány, a jog nem képes leírni. Így az ágens erre vonatkozó felkészültségeit negligálja, minek következtében az ágens ezen felkészültsége nem tud megmutatkozni, nem tudja a probléma tárgyára vonatkozó felismeréseit, interpretációját megjeleníteni. A feleket képviselő jogvégzett ember koalíciót alkot ügyfelével, azonban mint ágens ő sem képes megjeleníteni ezeket a dolgokat, lévén a jog nyelvén ez a legjobb esetben is csak körülírható.

Amennyiben a bíró az eljárást mediációba utalja, csak két dolgot köt feltételül: bizonyos időintervallumon belül fejeződjék be a mediációs eljárás, és a törvényben elöírt lajstromba vett $^{37}$ mediátorokat keressenek fel a felek. Az ilyen módon kötött megállapodásnak csak a realitástartalmát vizsgálja, ${ }^{38}$ jogilag nem értelmezi, nem elemzi, hanem ítéletbe foglalja. Azt, hogy a probléma megoldása közben azt a kialakult problémát, hogy a jog nem képes kezelni bizonyos helyzeteket, úgy oldja meg, hogy csak a kimenő és a visszajövő információkat vizsgálja, a két állapot közöttit semmilyen formában nem veszi figyelembe. Analógiát figyelhe-

${ }^{34} \mathrm{Az}$ interpretáció a megnyilatkozások ,értelme”, amely mindig egy adott ágens vagy ágensek interpretáció kapacitásaival van összefüggésben; ez az ágens sajátvilága (Horányi 2007: 110).

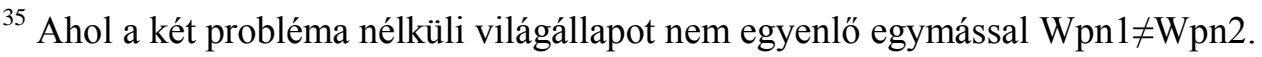

${ }^{36}$ A jog nyelvén leírni azt, hogy szerelem - mely meglehetősen sok per valódi okát képezi - nem lehet, legfeljebb körülírni.

${ }^{37}$ A Minisztérium által elismert és nyilvántartott mediátorok - megfelelő képzettségüket, büntetlen előéletüket igazolva - közvetítöi igazolványt kapnak. Tevékenységükről évente statisztikai adatokat közölnek a Minisztérium felé.

\footnotetext{
${ }^{38}$ Valóban a felek között született a megállapodás, és reálisan, életszerűen kivitelezhető.
} 
tünk meg a pszichológia behaviorista irányzatával, ${ }^{39}$ ahol az emberi szervezetet tekintették fekete doboznak, ${ }^{40}$ a jog pedig a mediáció folyamatát kezeli ily módon. Ezzel a mediáció jelentősége mint egy marginális segédtudomány a problémamegoldás jogi intézményi rendszerének a kereteihez, eredményéhez bennfoglalóan viszonyul, míg müködésétől elszeparálódik.

A jog problémamegoldó szemléletétől és struktúrájától eltérően a mediációs szemlélet a résztvevő feleket nem kizárólag az éppen a figyelem középpontjába került aktus révén vizsgálja. A mediációs folyamat mint színtér, minden körülmények között az ágens sajátvilágában lévő felkészültségeket és az ágensek közötti viszony változását helyezi a középpontba. Következésképpen a mediációs színtér mint $a b$ ovo szintér fogalom használható a participációs értelmezés szerint. Az ágens a felkészültségeivel van jelen oly módon, hogy azokat a folyamatban részt vevő többi ágens számára értelmezhető módon tudja kommunikálni.

Domschitz és Hamp szerint ,a színtér - legalábbis részben - változtatható az ágensek erőfeszítéseinek a következményeként (pl. amikor arra törekszünk, hogy valamiröl ne úgy beszéljünk, ahogyan eddig; ajánlatokat tehetünk a változtatásra), és spontán módon megváltozhat. Az átalakulásra való reflexióra vagy van az ágenseknek felkészültségük, vagy nincs" (Domschitz-Hamp 2007: 111). A mediációs színtér ettől abban tér el, hogy jelen van a színtéren egy olyan ágens is, aki a folyamat kontinuitásáért felelős, a mediátor. Ilyen kondíciók mellett a mediációs színtéren nem vagy nem csak spontán módon létrejött kommunikációs változásokról beszélhetünk. Az ágensek erőfeszítéseit pedig nagymértékben segítheti egy a kommunikáció folyamatosságának biztosításáért jelen lévő vezető-kísérő mediátor. A mediátor alapvetően befolyásolja a mediációs színteret az ágensek sajátvilágai különböző síkokon történő kifejezésének segítésével. A mediátor az ember egészére figyel, kommunikációjának minden lehetséges dimenziójára.

A tapasztalatok szerint a mediációs ülések elején nagyon erős az ágensek emocionális telítettsége. Amennyiben ennek - kellő szakmai felkészültséggel és méltósággal - teret adunk, idővel lejjebb ereszkedik az érzelmi szint, és így a sajátvilág megmutatkozása át tud tevődni a ráció talajára.

A mediációs színtér olyan kommunikációs színtér, ahol az ágensek a sajátvilágukban sokszor csak segítséggel felfedhető és aktivizálható képességeiket, felkészültségeiket használva közösen hoznak létre egy valamennyi résztvevő számára megfelelő új megoldást.

\subsubsection{A színtér fizikai tere}

A mediációs színteret a mediációt tudományos szemszögből vizsgáló és magyarázó irodalom egy olyan színtérként jellemzi, ahol a résztvevők még nem voltak jelen - legalábbis nem a mediációs a partnerekkel. Így ebben a térben - túl a mediáció jelenlegi szabályain (BushFolger 2005) - a mediátor képes vezetni a résztvevő feleket előzetesen elvárt viselkedési mintakontroll nélkül. ${ }^{41}$ Ennek a színtérnek van egy fizikai vonatkozása is, amely egyrészt mindkét

${ }^{39}$ A behaviorista irányzat képviselői szerint: ,„a tudományos pszichológia csak a környezeti ingerekről és a rájuk adott viselkedés válaszokról beszélhet. (Innét az irányzat neve is: viselkedéselvüség - azaz behaviorizmus.)" (Oláh 2006: 30)

${ }^{40}$ A fekete doboz (black box) a behaviorizmus vizsgálati jellemzője, mely szerint az objektivitás jegyében az egyént az ingerek és az arra adott válaszok (S-R) mentén kell vizsgálni (Pléh 2000).

${ }^{41}$ Ez a bírósági színtérhez viszonyítva azt jelenti, hogy a felek kifejezhetik érzéseiket, érzelmeiket a bíróságinál jóval szabadabban és szélesebb körben. Ennek határát - és egyben befolyását a folyamatra - a mediátor vezetésével a felek közösen szabályozzák. 
fél számára addig ismeretlen és ezáltal biztosítja a neutrális ${ }^{42}$ relációt. Másrészt ez a neutralitás képezi az alapot ahhoz, hogy a mediátor kialakíthassa azt az ergonómiailag is biztonságot, diszkréciót, nyugalmat adó fizikai teret - térbeli elrendezést -, amelyet a saját viselkedésével tovább tud erősíteni.

Az ergonómiai szempontok közül a mediáció során kiemelkedően fontos a figyelemelvonó hatások lehető legkisebbre redukálása. Az érzékelés egyes területei közül az audio és a vizuális ingerek kontrolállása a legfontosabb. Ez nem jelenti azt, hogy steril mesterséges környezetet kell applikálni a résztvevők köré, mert az - idegensége miatt - szintén negatív hatást válthat ki. A zaj, a fény, a hőmérséklet, mint környezeti befolyásoló tényezők optimális szinten tartása segíti a figyelem és a koncentráció fenntartását a három órás mediációs ülés alatt. Ideális állapotban ezek a nem tudatos érzékelésre ható tényezők a mediáció fizikai terében optimalizálásra kerülnek a mediátor által.

A mediációs folyamat során a kritikusan nehéz pontokon a figyelemelterelö környezeti ingerek a komfort zónában ${ }^{43}$ maradást segítik elő, megakadályozva az azon való túllépést. A komfort zónában maradás azonban nem cél a mediációs ülésen, éppen ellenkezőleg, a mediátor az ágensnek az aktív cselekvés zónájába vagyis a kihívás zónájába ${ }^{44}$ való segítésén dolgozik. A berendezés, a térben jelen lévő tárgyak és a megjelenő ingerek mellett a mediátor tudatos térelőkészítése és meghatározása szintén hatással van a mediációs színtér kialakulására. Egy válási ko-mediáció esetén például fontos, hogy a mediátorok átlósan szemben foglaljanak helyet az azonos nemü résztvevőkkel. Ez az optimális kiindulási pozíció a közös térhasználatban, amely a lehető legjobb kiindulási alapot adja a mediáció alatti poszturális ${ }^{45}$ és proxemikai ${ }^{46}$ kommunikációnak. A test mozgásérzékelését, illetve annak lehetőségét ugyan-is a létrehozható legneutrálisabb szinten tartja a nemek egyenlő eloszlása, biztonságos mozgásteret adva a nonverbális kommunikáció használatára.

Az ágensek nonverbális kommunikációjának kifejezésére és használatára az optimális lehetőséget és biztonságot a mediátor teremti meg a fizikai tér kialakításával és használatának irányításával. ${ }^{47}$ Erre azért van szükség, mert a nonverbális kommunikáció kiegészíti az ágensek verbális közléstartalmát, növelve annak könnyebb értelmezhetőségét, érthetőségét a közvetítő számára, amennyiben a megfelelően kialakított térben a nonverbális kommunikáció szabadon tud müködni kiegészítve a verbális kommunikációt.

A közös színtér használatában az ágenseket abban kell segíteni, hogy megtalálhassák a kommunikáció legnagyobb részét kitevő nonverbális kommunikációjuknak az optimális müködését.

${ }^{42}$ A neutralitás azért fontos, mert nem kapcsolódhatnak a fizikai térhez olyan emlékek, amelyek mintaként rögzülve megvezetnék a feleket érzékelésükben, viselkedésükben.

${ }^{43}$ A komfort zóna egy viselkedési forma, amelyen belül a személy szorongásmentes állapotban, korlátozott számú viselkedési minta aktivizálása mellett képes egy megközelítőleg állandó szintü teljesítményt nyújtani általában anélkül, hogy bármifajta kockázati tényező jelen lenne a folyamatban (White 2009).

${ }^{44}$ Kihívás vagy aktív cselekvési zóna az a viselkedési forma, amelyen belül a személy az őt ért külső ingerek hatására aktivitásba, cselekvésbe kezd a változás érdekében, új viselkedési mintákat felhasználva. A kihívás zónában való sikeres tevékenység eredményeképpen egy más minőségü komfortzóna kerül kialakításra (White 2009).

${ }^{45}$ Testtartás általi kommunikáció.

${ }^{46}$ A kommunikáció és a hétköznapi tevékenységek során betartott személyek közötti távolság, a tér emberi felhasználása.

${ }^{47}$ A résztvevő felek nem ismerik a mediációs színteret az első alkalommal, így ismertetni kell velük használatának határait, például felállhatnak, hátradőlhetnek, stb. 


\subsubsection{A színtér és az idő összefüggése}

A mediáció vizsgálata, illetve leírása során az idő használata kiemelt fontossággal bír. Az interperszonális kommunikációk különböző típusai során elkülöníthető szakaszokra különböző mennyiségü idő jut. Ez igaz a mediációs folyamatra is.

Amennyiben nincs meg a megfelelő idő az érzékelésre, a korábbiakhoz képest újat jelentő információk feldolgozására értelmi és érzelmi szinten egyaránt, úgy az ágensek nem tudják a sajátvilágba integrálni a probléma megoldásához szükséges változásokat.

A felek látási lehetőségeinek kiszélesítéséhez több időre van szükség, mint más, addig megszokott vitarendezési környezetben, például egy bírósági tárgyalóteremben. Sokszor a felek a mediációs időben, a sajátidőben jönnek rá, hogy hogyan is alakult ki bennük egy okokozati összefüggés, ami az üggyel kapcsolatban a későbbiek során egy célt tévesztett cselekedetben manifesztálódott.

A bizalmi légkör megteremtése a mediátor feladata, amelyhez a megfelelö kommunikációs technikákon kívül elengedhetetlenül szükséges a megfelelő idő hozzárendelése. Ez egyfajta ráhangolódás idő, amely azt a célt szolgálja, hogy a mediációban résztvevők kommunikációs szempontból érzékeljék a biztonságos, diszkrét, nyugodt környezetet.

A szükséges idő biztosítása a résztvevő feleknek lehetőséget ad arra, hogy aktív figyelmet kapjanak a sajátviláguk feltárására. Ez a folyamat - a saját tapasztalataim és adatgyüjtéseim alapján - ott tud végbemenni, ahol adottak a szükséges feltételek, így:

- a problémát megjeleníteni képes ágensek,

- a folyamatot vezető és a feleket követő, azok kommunikációját megfelelően érzékelő mediátor,

- a megfelelő szintü biztonságot nyújtó színtér,

- a megfelelő mennyiségü és minőségü idő.

Ennek az időnek jelentős része az adott helyzettel kapcsolatos emóciók, félelmek megmutatkozásával telik. Amennyiben kellő idő van biztosítva a múltbeli sérelmekhez kapcsolódó fájdalmak és az egyértelmủen megváltozó jövővel kapcsolatos félelmek kölcsönös megjelenítésére, úgy ez által elkezdhet újraépülni a résztvevő ágensek közötti bizalmi viszony - ez már a probléma létrejöttéhez kapcsolódó sajátvilág megmutatkozásának első lépcsőfoka. Amenynyiben az emocionális szinten a kapcsolat helyreállt, az ágensek képessé válnak tudatos szintre emelni a megoldandó problémát és ezen a tudatos színtéren keresni annak lehetséges megoldásait is. Az ágensek számára tehát nemcsak a szükséges időmennyiség fontos a megfelelő színtéren, hanem az időegységhez hozzárendelt tematikus sorrendiség is: elsőként emocionális szint, majd tudatos, racionális szint. 


\section{IRODALOM}

Berne, Eric (2002) Emberi Játszmák. Budapest, Háttér Kiadó.

Bogacz, Francois - Lack, Jeremy (2010) The social brain during the mediation. The tentative model. Mediation World Conference, Ljubjana.

Bono, Edward de (1994) Paralell thinking. London, Viking.

Bush Baruch, Robert A. - Folger, Joseph P. (2010) Transformative Mediation and ThirdParty Intervention: Ten Hallmarks of a Transformative Approach to Practice. Mediation Quarterly, Volume 13, Number 4. https://doi.org/10.1002/crq.3900130403

Bush Baruch, Robert A. - Folger, Joseph P. (2004) The Promise of Mediation: The Transformative Approach to Conflict. 2nd ed. San Francisco, Jossey-Bass Publishers.

Domschitz Mátyás - Hamp Gábor (2007) A kommunikáció színtereiről. In: Horányi Özséb (2007szerk.) A kommunikáció mint participáció. Budapest, Typotex.

Frith, Chris D. - Frith, Uta (2007) Social cognition in humans. Current Biology. Vol.17, Issue 16. 724-732. https://doi.org/10.1016/j.cub.2007.05.068

Herrman, Margaret S. - Hollett, Nancy - Gale, Jerry - Foster, Mark (2001) Defining Mediator Knowledge and Skills. Negotiation Journal, Vol,17, No 2. 139-153. https://doi.org/10.1111/j.1571-9979.2001.tb00232.x

Horányi Özséb (2007szerk) A kommunikáció mint participáció. Budapest, Typotex.

James, Lawrence. R. - Brett, Jeanne M. (1984) Mediators, moderators and tests for mediation. Journal of Applied Psychology, Vol. 69. 307-321. https://doi.org/10.1037/0021-9010.69.2.307

Judd, Charles. M. - Kenny, David A. (1981) Process analysis: Estimating mediation in treatment evaluations. Evaluation Review, Vol.5. 602-619. http://dx.doi.org/10.1177/0193841X8100500502

Lewin, Kurt (1972) A mezőelmélet a társadalomtudományban. Budapest, Gondolat.

Oláh Attila (2006) Pszichológiai alapismeretek. Budapest, Bölcsész Konzorcium.

Pete Krisztián - P. Szilczl Dóra (2007) A kommunikáció intézményeiről. In: Horányi Özséb (2007szerk.) A kommunikáció mint participáció. Budapest, Typotex

Pléh Csaba (2000) A lélektan története. Budapest, Osiris Kiadó.

Santa Maria, Diana - Gregg, Marc A. (1997) Seven steps to effective mediation. The Trial Lawyer Magazine. Vol. 33., No.2. Washington DC.

Sheldrake, Rupert (2009) Morphic Resonance. The Nature of Formative Causation. Rochester, Park Street Press.

White, Alasdair A. K. (2009) From Comfort Zone to Performance Management. La Houlette, White \& MacLean Publishing.

Wood, John (2004) Mediation styles: Subjective description of mediators. Conflict Resolution Quarterly. Vol. 21, No. 4. 437-450. https://doi.org/10.1002/crq.72 